\title{
RADIOFREQUENCY AS PAIN INTERVENTIONAL THERAPY IN NEUROLOGY
}

\author{
Badrul Munir ${ }^{1}$, Widodo Mardi Santoso ${ }^{1}$, Zamroni Afif ${ }^{1}$, Shahdevi Nandar Kurniawan ${ }^{1}$ \\ ${ }^{I}$ Neurology Department, Medical Faculty, Brawijaya University, Saiful Anwar General Hospital, Malang, Indonesia. \\ Correspondence : badroel2007@ub.ac.id
}

\begin{abstract}
Radiofrequency (RF) intervention uses high frequency alternating current (AC) to inhibit and alter nociceptive pathway in various locations. Radiofrequency is divided into Continuous RF (CRF) and Pulsed RF (PRF). Continuous RF is a process in which the RF current is used to produce thermal lesions on the target nerve that will result in resistance to the afferent nociceptive pathway. PRF is a process whereby short bursts of RF are discharged toward a neural target that will produce a signal for lowering pain. PRF is a therapy of neural tissue with small neurodestructive possibility and is an alternative technique for continuing RF. RF therapy is a minimally invasive procedure that has been used for about three decades to treat various chronic pain syndromes such as trigeminal neuralgia, post herpes neuralgia, lower back pain (LBP), and complex regional pain syndromes or sympathetic reflex dystrophy. The mechanism action of the PRF involves cellular structure damage, neuronal activation, altered gene expression, a global continuation of evoked synaptic activity in pain fibers through centrals and changes in synaptic strength and long-term potentiation. PRF with its various characteristics has a better outcome than conventional RF.
\end{abstract}

Keyword : Radiofrequency, continuous RF, pulsed RF

\section{PENDAHULUAN}

Nyeri merupakan pengalaman sensorik multidimensi yang tidak menyenangkan akibat kerusakan jaringan. Kelompok studi nyeri Perdossi (2000) telah menterjemahkan definisi nyeri yang dibuat oleh IASP (International Association The Study of Pain) yang berbunyi "nyeri adalah pengalaman sensorik dan emosional yang tidak menyenangkan akibat kerusakan jaringan, baik aktual maupun potensial, atau yang digambarkan dalam bentuk kerusakan tersebut (1).

Terdapat beberapa modalitas penatalaksanaan nyeri diantaranya terapi farmakologis mulai dari yang sederhana hingga dengan kombinasi berbagai macam jenis obat, terdapat juga terapi non farmakologis berupa terapi psikologis dan fisik, tetapi untuk nyeri terutama nyeri kronik sendiri hingga saat ini masih menjadi salah satu tantangan terbesar bagi kebanyakan ahli neurologi dalam praktik seharihari dikarenakan perbedaan respon pada setiap individu (2).

Terapi radiofrekuensi (RF) merupakan prosedur invasive minimal yang telah digunakan sekitar tiga dekade untuk mengobati berbagai sindroma nyeri kronik seperti trigeminal neuralgia, post-herpetic neuralgia, low back pain (LBP), dan juga complex regional pain syndrome atau reflex sympathetic dystrophy (3).

\section{DEFINISI RADIOFREKUENSI}

Radiofrekuensi (RF) merupakan prosedur menggunakan arus $\mathrm{AC}$ (alternating current) frekuensi tinggi untuk menghambat atau merubah jalur nociceptive pada berbagai lokasi. Continuous RF (CRF) merupakan suatu proses dimana arus RF digunakan untuk menghasilkan lesi termal pada target saraf yang akan menghasilkan hambatan pada jalur nosiseptif aferen. Pulsed RF (PRF) merupakan suatu proses dimana short bursts dari RF dihantarkan menuju ke target saraf yang akan menghasilkan sinyal tranduksi untuk menurunkan nyeri4. Pulsed radiofrekuensi (PRF) merupakan terapi dari jaringan saraf dengan kemungkinan neurodestructive yang kecil dan merupakan teknik alternatif untuk continue RF (5).

\section{ALAT DAN INSTRUMENT PADA RADIOFREKUENSI}

\section{Generator}

Radiofrekuensi ablasi terdiri dari generator dan elektroda. Kebanyakan generator memiliki 2 terminal. Generator menghasilkan output $150-200 \mathrm{~W}$ arus bolak balik frekuensi tinggi melalui elektroda radiofrekuensi. Sebagian besar generator ini memiliki daya maksimum antara 50 dan $100 \Omega$ (6).

\section{Article History (Filled by Editor):}

Received: 1 Agustus 2020; Accepted: 20 Agustus 2020; Published: 1 September 2020

Cite As: Vancouver style

Munir B, Santoso WM, Afif Z, Kurniawan SN. Radiofrequency as pain interventional therapy in neurology. Journal of Pain, Vertigo and Headache; 2020.1:31-36 


\section{Elektroda}

Elektroda radiofrekuensi terdiri dari jarum metalik dengan ujung cutting tip. Isolator ditempatkan di sebagian besar pada poros elektroda dan ujung yang aktif.

Panjang dan diameter maksimum zona ablasi kira-kira sama dengan panjangnya exposed tip dengan zona ablasi hanya membentang beberapa mm di depan ujung elektroda dengan teknologi saat ini, elektroda frekuensi radio bervariasi dari 10 sampai $20 \mathrm{~cm}$ dan diameter $16-20 \mathrm{G}$. Dengan peningkatan panjang dari elektroda juga akan meningkatkan panjang dan lebar dari zona ablasi (7).

\section{MEKANISME KERJA RADIOFREKUENSI}

Arus RF merupakan energi rendah dengan arus AC frekuensi tinggi $(50-500 \mathrm{kHz})$ yang diaplikasikan pada jaringan biologis, hal itu menyebabkan molekul jaringan berosilasi sehingga menyebabkan gesekan antar molekul dan panas. Jika arus diterapkan untuk waktu yang cukup, panas yang cukup akan dihasilkan untuk menyebabkan koagulasi, atau lesi termal, sesuai target jaringan (8).

Mekanisme yang mendasari radiofrekuensi adalah adanya arus listrik di sekitar ujung jarum. Perubahan arus menyebabkan pergerakan ion-ion listrik. Pergerakan ion menyebabkan friksi kemudian menghasilkan panas di sekitar ujung jarum yang akan menyebabkan kerusakan saraf. Sel mengalami kerusakan pada suhu $45^{\circ} \mathrm{C}$. Pada suhu $60^{\circ} \mathrm{C}-$ $100^{\circ} \mathrm{C}$, terjadi induksi koagulasi protein yang menyebabkan kematian sel. Suhu standar pada ablasi adalah $80^{\circ} \mathrm{C}$ dalam waktu 60 detik.

Pada CRF menggunakan energi panas yang dihasilkan dari ujung elektroda aktif. Elektroda harus diposisikan disamping target saraf untuk menghasilkan lesi optimal. Lesi optimal terjadi pada waktu 60-90 detik. Sedangkan Pulsed radiofrekuensi (PRF) merupakan terapi dari jaringan saraf dengan kemungkinan neurodestructive yang kecil dan merupakan teknik alternatif untuk continue RF (5).

Mekanisme kerja dari PRF saat ini sedang menjalani penelitian yang luas. Pada saat ini, kebanyakan studi menunjukkan terjadi perubahan dalam transmisi sinaptik, dalam efek neuromodulator (9). Sebuah teori populer adalah bahwa bidang elektro berubah dengan cepat karena PRF mengubah transmisi sinyal rasa nyeri melalui jalur melibatkan c-Fos, studi sebelumnya telah menunjukkan bahwa PRF meningkatkan ekspresi c-Fos di cornu dorsalis, serta respon yang berkelanjutan selama 7 hari setelah pengobatan. Hasil ini juga menunjukkan penghambatan rangsang serabut $\mathrm{C}$ dalam jangka panjang (10).

Mekanisme aksi dari PRF bermacam-macam dan mungkin melibatkan kerusakan struktur seluler, aktivasi neuronal, perubahan ekspresi gen (aktivasi respon gen awal kemudian mengubah ekspresi gen yang teraktivasi adalah faktor transkripsi, sehingga perubahan dalam ekspresi gen muncul dalam jangka panjang, tidak terbatas pada stadium awal); pengurangan global dari aktivitas evoked synaptic mengarah pada pengurangan transmisi impuls nyeri melalui serabut $\mathrm{C}$ dan $\mathrm{A}_{\delta}$ melalui depresi jangka panjang dan perubahan synaptic field strength dan long-term potentiation. Keseluruhannya berpotensial mengurangi transmisi impuls nyeri.

\section{Perubahan Struktural dan Ultrastruktural Seluler}

Disfungsi sel dapat terjadi secara sekunder akibat dari tingginya gelombang elektromagnetik RF dan letupan panas dari PRF. Cosman mendemonstrasikan bahwa gelombang elektrik yang berasal dari PRF mampu merubah membran neuronal. Studi neurobiologi menunjukkan perubahan awal dan akhir pada aktivitas seluler, yang mana terpisah dari pengaruh suhu, terjadi pada kornu dorsalis tikus, cervical dorsal root ganglion (DRG) setelah terekspose PRF. Aktivasi neuronal telah didemonstrasikan pada beberapa studi eksperimental PRF (11).

Erdine et al menganalisis perubahan ultrastruktural setelah dilakukan PRF dan menunjukkan bahwa paparan PRF menghasilkan kerusakan yang relatif kecil pada serabut $C$ dan $\mathrm{A}_{z}$ dengan perubahan pada morfologi mitokondria, termasuk perubahan membran dan gangguan serta disorganisasi mikrofilamen bersama akson. Didapatkan juga perubahan mikroskopis pada membran akson, seperti perubahan pada kanal atau pompa ion juga muncul tetapi kemungkinan tidak terbukti selama evaluasi menggunakan mikroskop elektron. Derajat dan selektivitas dari kerusakan ultrastruktural terlihat berhubungan dengan penetrasi gelombang elektrik PRF. Konsep ini yang mana gelombang berpenetrasi pada membran sel akson dari serabut $\mathrm{C}$ dan $\mathrm{A}_{\delta}$, mengakibatkan gangguan struktur lebih dalam lebih besar. Kalkulasi gelombang elektrik yang lebih dalam untuk tiap jenis serabut berespon pada derajat dan selektivitas dari kerusakan ultrastruktural. Kerusakan pada mitokondria, melalui fragilitas membran, mengakibatkan gangguan pada fungsi utama adenosine triphosphate-mediated cellular dan pada metabolisme seluler, yang berdampak pada sinyal nyeri. Kerusakan pada mikrotubulus dan mikrofilamen bisa menghalangi transmisi impuls nyeri (11).

\section{Perubahan Struktur Gen}

Berbagai studi kultur sel telah menunjukkan perubahan pada aktivitas kornu dorsalis dan peningkatan stres seluler pada neuron berkaliber kecil dan medium dalam merespon PRF. Aplikasi PRF pada kultur sel juga menginduksi ekspresi gen awal yang mana tidak dimediasi oleh panas. Studi in vivo yang membandingkan RF dan PRF mendemonstrasikan peningkatan pada c-fos neuron imunoreaktif pada lamina superfisial dari kornu dorsalis 3 jam setelah PRF, tetapi tidak pada RF konvensional, pada DRG, menunjukkan aktivasi neuron yang memproses nyeri tidak dimediasi oleh panas 12 . Van Zundert et al melaporkan bahwa peningkatan sel imunoreaktif c-fos di kornu dorsalis dicatat 7 hari setelah continuous RF kedua dan PRF pada cervical dorsal root, menunjukkan aktivasi neuronal yang terlambat. Sebagai tambahan, Hamman et al memunculkan adanya upregulasi activating transcription factor 3 (ATF3) pada badan sel neuronal DRG tetapi tidak pada bagian saraf lainnya, seperti pada nervus ischiadicus, yang dilakukan PRF. ATF3 merupakan marker dari stres selular dan neuropati, upregulasinya mengindikasikan bahwa PRF memiliki efek biologis yang terpisah dari kerusakan panas. Ekspresi dari gen c-fos mengarah pada formasi dari second RNA messenger, preprodinorphin, yang mana meningkatkan produksi endorfin yang dapat memodulasi analgesik. Ekspresi dari c-fos juga berperan sebagai eksitator dan inhibitor neuron dan kornu dorsalis medula13. Secara keseluruhan, perubahan gen ekspresi yang diinduksi oleh 
PRF dapat merefleksikan perubahan komponen pada neuron kornu dorsalis pada arahnya mengurangi nosisepsi (11).

\section{Efek Biologis}

Dalam sebuah studi evaluasi histologi pada hewan tentang dampak histologis RF terus menerus pada $67^{\circ} \mathrm{C}$ dan PRF pada dorsal root ganglia (DRG) kelinci. Erdine et al menemukan degenerasi mitokondria dan hilangnya keutuhan membran sel tetapi tidak dalam kelompok PRF. Studi histopatologi, yang membandingkan efek continue RF dan PRF $42^{\circ} \mathrm{C}$ pada DRG dan saraf sciatic tikus, menunjukkan tidak ada perubahan struktural selain dari edema endoneurial sementara dan deposisi kolagen. Pada studi terbaru terdapat perubahan aksonal ultrastruktur menunjukkan kerusakan mikroskopis setelah paparan PRF, membran yang abnormal dan morfologi mitokondria, dan gangguan dan disorganisasi mikrofilamen dan mikrotubulus (14).

Studi mirip yang lain menunjukkan bahwa kerusakan akson bermielin hanya menunjukkan pemisahan pada konfigurasi myelin Setelah PRF selama 120 detik. Selain itu, akson mielin yang baru dibentuk juga diamati pada kelompok ini . Temuan histologis ini diyakini sebagai hasil dari Potensial tinggi transmembran yang dihasilkan jaringan yang terekspos selama aplikasi PRF (15).

\section{INDIKASI RADIOFREKUENSI DI BIDANG NEUROLOGI}

Aplikasi radiofrekuensi dapat diberikan pada banyak kondisi klinis seperti nyeri pada facet joint, trigeminal neuralgia, complex regional pain syndrome, cancer pain penggunaan pulsed radiofrequency merupakan metode non-neurodestruksi dengan nyeri minimal sebagai alternative dari radiofrekuensi continue.

\section{Nyeri Punggung Belakang}

\section{Nyeri cervical}

Nyeri kronik pada cervical dapat mucul dari beberapa struktur regio cervical termasuk sendi zygaphophiseal, segement saraf cervical, ligament dan myofascial (16).

Saat ini terdapat dua aplikasi yang diterima dari pengobatan radiofrekuensi pada area cervical. Yakni radiofrekuensi denervasi pada cabang medial atau denervasi facet untuk manajemen nyeri leher dan atau cervicogenic headchache dan yang kedua terapi dengan menggunakan pulsed radiofrekuensi dari dorsal root ganglion dalam pengobatan nyeri radikular pada $(16,17)$.

Terapi radiofrekuensi pada area yang berdekatan dengan DRG, telah dilaporkan oleh Van Kleef et al, namun adanya efek samping berupa transient neuritis dan hilangnya kekuatan otot tangan telah dilaporkan. Dikarenakan efek samping dan kemungkinan interupsi dari jalur aferen maka PRF pada DRG cervical menjadi cukup popular. Van Zundert et al melaporkan dampak dari grup yang telah diberikan PRF dibanding yang tidak diberikan PRF pada 3 bulan menunjukkan adanya perbaikan signifikan secara global (>50\% perbaikan) (18).

\section{Nyeri Thorakal}

Penyebab dari nyeri regio thorakal antara lain neuralgia intercostal, neuralgia dari dinding abdominal, lalu nyeri menjalar dari medulla spinalis yakni akibat osteoporosis, ataupun collapse vertebrae (19).

Dua publikasi menunjukkan hasil yang memuaskan antara grup dengan terapi RF pada manajemen thoracic radicular pain. Stolker et al melakukan evaluasi pada 45 pasien dengan thoracic radicular pain. Didapatkan penurunan signifikan dari nyeri pada > dari $70 \%$ pasien 13-46 bulan setelah terapi. Studi mirip yang lain dilakukan oleh van Kleef dan Spaans mendapatkan $52 \%$ pasien mengalami penurunan nyeri yang signifikan pada 9-30 bulan (19).

\section{Nyeri Lumbal}

Vertebra lumbalis terdiri dari lima ruas tulang atau nama lainnya adalah ruas tulang pinggang, luas tulang pinggang adalah yang terbesar. Taju durinya lebar dan berbentuk seperti kapak kecil. Taju sayapnya panjang dan langsing. Ruas kelima membentuk sendi dan sacrum pada sendi lumbo sacral.

Target radiofrekuensi adalah cabang medial dari ramus primer posterior dari lumbal (L1-L4), hubungan antara processus artikularis superior dan permukaan atas dari bagian lateral dari sacrum (L5) sebelah lateral dari foramen sacralis (S1-S3).

Nyeri radikuler pada lumbosacral adalah nyeri khas yang berasal dari tulang belakang dan memancar dalam satu atau lebih segmen lumbosakral. Informasi yang bermakna diperoleh dari anamnesis adalah tentang distribusi nyeri. Test lasseque memiliki sensitivitas tinggi dan spesifisitas rendah. Pemeriksaan neurologis dapat membantu untuk menentukan tinggi level yang terkena. Radiofrequency lesioning dari dorsal root ganglion telah dilakukan studi dengan prospective randomized study yang tidak menunjukkan kesuperioritasan untuk terapi RF (20).

Radiofrekuensi pada dorsal root ganglion lumbal diindikasikan pada kasus dengan nyeri radikular. Bukti menunjukkan bahwa PRF bermanfaat dalam mengobati baik nyeri radikuler cervical maupun lumbal. Tidak ada komplikasi tercatat $(50 \%-70 \%)$ sampai sekitar 2 sampai 4 bulan setelah terapi. Dalam pengobatan nyeri radikuler lumbal, kurangnya manfaat tambahan ketika RF dikombinasikan dengan PRF pada penelitian Simopoulos et al yang menunjukkan bahwa efek gelombang listrik (dan bukan panas) adalah faktor modulasi; ini berkorelasi dengan data ilmu dasar yang menyoroti bahwa ada perubahan struktural atau ultrastruktur serta perubahan ekspresi gen, termasuk upregulasi dari ATF3.

\section{Trigeminal Neuralgia}

Nervus trigeminus merupakan nervus terbesar di antara 12 nervus cranialis dan merupakan saraf kranial yang kompleks. Nervus ini merupakan nervus campuran (mixed nerve) yang memiliki komponen mayor berupa saraf sensoris (somatic afferent fibers) untuk wajah dan komponen minor berupa saraf motoris (special somatic efferent) untuk otot-otot mengunyah (mastikasi).

Trigeminal neuralgia juga disebut "tic douloureux" karena adanya pada saat meringis ke satu sisi menunjukkan rasa sakit/ nyeri pedih yang terbatas pada distribusi satu atau lebih divisi dari saraf trigeminal. Diagnosis biasanya dibuat berdasarkan deskripsi pasien tentang rasa sakit dan rangsangan yang memprovokasi. Untuk mengekslusi adanya 
massa lesi CT scan atau MRI diindikasikan. Manajemen farmakologis adalah pengobatan pilihan pertama tetapi pada pasien yang menderita trigeminal neuralgia refraktori untuk terapi radiofrekuensi pada gasserian bisa dipertimbangkan (20).

Teknik perkutan dilakukan seperti yang dijelaskan pertama kali oleh Sweet et al. tahun 1974. Dalam prosedur ini, pasien berbaring dengan nyaman dalam posisi telentang dengan kepala agak melebar. Elektrokardiogram, denyut nadi dan oksimetri dan pembacaan tekanan darah dilakukan untuk pemantauan hemodinamik terus menerus, $\mathrm{C}$-arm dalam mode postero-anterior dan secara diputar caudo-kranial untuk menghasilkan pandangan submental. Foramen ovale seringkali bisa divisualisasikan dengan posisi ini. Kemiringan 5-10 derajat ke sisi ipsilateral yang terkena mungkin diperlukan untuk memperbaiki visualisasi foramen ovale, Titik masuk jarum berjarak 2-3 cm sudut mulut. Dilakukan anaestesi dengan lidokain $1 \%$ pada bagian atas kulit yang akan disuntik. Sampai 0,75 mg / kg propofol digunakan untuk menenangkan pasien selama penetrasi jarum awal ke foramen ovale. Begitu jarum memasuki foramen ovale lalu Meckel's cavity, C-arm kemudian diputar ke lateral untuk memastikan kedalaman penetrasi. Posisi akhir ujung jarum hanya melewati sudut yang dibentuk oleh punggungan petrosal ridge dari tulang temporal dan clivus. Propofol dihentikan, pasien dibiarkan terbangun, dan stimulasi sensori dilakukan pada suhu $50 \mathrm{~Hz}$. Pengecekan posisi elektroda dengan cara menginduksi paresthesia dengan stimulasi sensorik antara 0,1-0,3 V pada area yang nyeri. PRF diaplikasikan selama 6 menit pada $45 \mathrm{~V}$ dengan panjang gelombang $10 \mathrm{~ms}$ dan frekuensi $4 \mathrm{~Hz}$, dengan cut off suhu di setting $42^{\circ} \mathrm{C}$ (18).

Penelitian oleh Erdine et al pada kasus trigeminal neuralgia secara randomized, prospective, dan studi double-blind selama 6 bulan, didapatkan pada grup RF didapatkan penurunan nyeri secara signifikan (21).

\section{Trigeminal Oksipital}

Neuralgia oksipital juga disebut Arnold's neuralgia, diartikan oleh International Headache Society sebagai nyeri yang paroksismal, menusuk pada greater, lesser dan atau distribusi saraf third occipital intensitas nyeri seringkali berat dan menyebabkan kelemahan dan berhubungan dengan kualitas hidup fungsional. Kasus ini sebagian besar etiologinya adalah idiopatik tanpa adanya kelainan strukutral (22).

Prosedur radiofrekuensi untuk terapi pada occipital neuralgia, migraine dan cervicogenic headchaches dengan target pada greater occipital nerve (C2), lesser occipital nerve (C3) (23).

Studi klinis mengenai efikasi dari PRF sebagai terapi dari neuralgia occipitalis telah menunjukkan hasil yang menjanjikan, yakni perbakan dari nyeri, kualitas hidup dan penggunaan anti nyeri tambahan (22).

Penelitian yang telah tersedia menunjukkan hasil secara statistik menunjukkan perbaikan nyeri yang signifikan setelah terapi PRF. Navani et al menunjukkan adanya perbaikan nyeri $60-70 \%$ secara berkelanjutan setelah 4 bulan dari terapi awal dan 5 bulan setelah terapi kedua. Vanelderen et al melaporkan perbaikan nyeri pada sekitar $50 \%$ lebih pengecekkan di bulan ke 2 dan 6 didapatkan perbaikan nyeri pada VAS skor, perbaikan pada gangguan tidur, gangguan mood, dan gangguan pada aktivitas sehari-hari (22).

\section{CRPS}

Klasifikasi CRPS menurut IASP 1994 dibagi menjadi dua, yaitu : CRPS tipe I atau reflek sympathetic dystrophy (RSD), Symphatetic maintenated pain (SMP) dan CRPS tipe II atau causalgia (24).

Definisi CRPS I adalah nyeri difus pada ekstremitas umumnya seperti terbakar, nyeri dalam spontan (berdenyut, ditekan, menyentak) dan biasanya akibat trauma atau stimulasi noxious yang menyebabkan kelainan sensorik ( hiperestesia, hiperalgesia, alodinia terhadap stimuli dingin dan mekanik, motorik (kelemahan, tremor, persendian kaku), otonomik (perubahan aliran darah, suhu local hangat/dingin, warna kulit merah/pucat, hiper/hipo-hidrosis, edema dan trofik (atrofi otot, osteopenia, artropati, kulit licin, kuku rapuh dan perubahan pertumbuhan rambut). Bisa disertai gangguan psikologis reaktif (ansietas, depresi, putus asa).

Definisi CRPS II adalah nyeri terbakar disertai adanya alodinia, hipestesia, parastesia dan hiperpatia yang sesuai dengan dermatom atau distribusi saraf tepi yang disertai dengan kelemahan otot yang menyebabkan kelainan sensorik ( hiperestesia, hyperalgesia, alodinia terhadap stimuli dingin dan mekanik), Motorik (kelemahan, tremor, persendian kaku), Otonomik (perubahan aliran darah, suhu local hangat /dingin, warna kulit merah/pucat, hiper/hipo-hidrosis, edema dan Trofik (atrofi otot, osteopenia, artropati, kulit licin, kuku rapuh dan perubahan pertumbuhan rambut). Bisa disertau gangguan psikologis reaktif (ansietas, depresi, putus asa).

Pada umumnya ditemukan di tangan atau kaki, setelah trauma parsial pada satu saraf atau cabang utamanya. Awitan dari nyeri biasanya segera setelah terjadinya trauma (timbul beberapa jam sampai beberapa hari setelah terjadinya trauma) (25).

Telah dilakukan PRF pada pasien dengan tanda analgesia pada diagnostik lumbar sympathetic block, dan dilanjutkan PRF pada lumbar sympathetic ganglia setinggi vertebrae L2, L3, dan L4. Hasilnya terdapat penurunan skor nyeri VAS dari $95 \mathrm{~mm}$ (sebelum prosedur) menjadi $25 \mathrm{~mm}$ pada hari ke-10 setelah prosedur dilakukan. Perubahan vasomotor dan sudomotor menghilang dalam waktu 3 hari PRF. Hasilnya menjadi stabil selama 4 bulan diikuti (26).

\section{Nyeri Lutut}

Sendi lutut diinervasi oleh cabang artikular dari berbagai saraf, termasuk femoral, saraf peroneal, saphena, tibialis dan obturator. Cabang artikular ini

sekitar sendi lutut dikenal sebagai saraf genicular. Saraf genicular dapat dengan mudah ditemukan secara perkutan di bawah bimbingan fluoroskopik.

Cabang genicular dari sendi lutut terdiri dari superior lateral (SL), middle, superior medial (SM), inferior lateral (IL), inferior medial (IM), dan recurrent tibial genicular nerve . Target termasuk SL, SM and IM saraf genicular. Indikasi blok saraf genicular antara lain pasien dengan nyeri kronik akibat OA, pasien dengan gagal dari knee replacement, pasien yang tidak bisa dilakukan knee replacement, pasien yang tidak ingin dioperasi.

Nyeri lutut kronis akibat osteoartritis atau artroplasti adalah masalah yang sering terjadi. Sejumlah publikasi telah melaporkan keberhasilan prosedur radiofrekuensi (RF) pada saraf yang menginervasi lutut. Perawatan radiofrekuensi pada 
sendi lutut (suplai saraf utama atau periarticular atau cabang intra-artikular) berpotensi mengurangi rasa sakit akibat osteoartritis atau nyeri pasca artroplasti.

Sluijter et al. menerangkan serangkaian laporan kasus yang mengevaluasi penggunaan PRF dalam pengobatan nyeri sendi lutut arthrogenic kronis, sendi radiocarpal, sendi bahu, dan sendi atlantoaxial. PRF dilakukan pada pasien yang gagal pengobatan konservatif maupun pengobatan invasif lainnya. Penurunan nyeri tercatat dalam setiap kasus, dengan durasi efek yang berlangsung 8-12 bulan.

\section{Nyeri Sendi Bahu}

Sendi bahu merupakan sendi yang kompleks pada tubuh manusia. Persendian ini dibentuk oleh tulang-tulang yaitu : scapula (shoulder blade), clavicula (collar bone), humerus (upper arm bone), dan sternum. Daerah persendian bahu mencakup empat sendi, yaitu sendi sternoclavicular, sendi glenohumeral, sendi acromioclavicular, sendi scapulothoracal. Empat sendi tersebut bekerjasama secara sinkron. Sendi glenohumeral mempunyai lingkup gerak sendi yang sangat luas karena caput humeri tidak masuk ke dalam mangkok sendi.

PRF pada nervus supraskapularis pertama kali dijelaskan pada tahun 2002. Rohof, mengevaluasi PRF pada nervus supraskapularis dengan melakukan analisis retrospektif dari 37 studi pasien dengan nyeri bahu kronis. Setelah pengobatan, rata-rata penurunan skala nyeri tercatat 4,5 poin (dari 10 total poin). Shah dan Racz melaporan kasus seorang pasien dengan adhesive capsulitis dan osteoarthritis menjalani 4 perawatan PRF pada saraf supraskapularis selama periode 16-bulan. Penulis menyimpulkan bahwa PRF dengan mudah menurunkan intensitas nyeri, dan meningkatkan fungsional rata-rata 12-18 minggu. Pada tahun 2009, Liliang et al. mengerjakan PRF pada 13 bahu 11 peserta studi yang gagal perawatan konservatif. Subyek dilaporkan penurunan yang signifikan pada nyeri bahu dan indeks kecacatan pada 6 bulan. Selain itu, 9 dari 11 pasien nyerinya mereda setelah dilakukan PRF. Kane et al. mengevaluasi efek dari PRF pada 12 pasien dengan arthropathy of the rotator cuff dalam konteks komorbiditas medis yang signifikan. Skor pasien membaik dibandingkan dengan nilai awal VAS, Oxford Shoulder Score, dan Constant Shoulder Score pada bulan ke 3 dan 6 (11).

\section{KOMPLIKASI}

Secara teoritis, PRF dengan berbagai karakteristiknya memiliki prospek yang lebih baik daripada RF konvensional. PRF merupakan prosedur yang relatif aman. Pada RF yang konvensional, sering dikaitkan dengan neuritis, defisit motorik, dan risiko deafferensiasi nyeri, PRF tampaknya hanya memiliki lebih sedikit efek samping. Hingga saat ini pada kasus yang telah dilakukan PRF belum didapatkan adanya laporan untuk reaksi efek samping pasca tindakan namun dianjurkan untuk peletakan elektroda tidak terlalu dekat dengan segment saraf (26). Terapi radiofrekuensi telah menjadi salah satu pilihan terapi pada kasus nyeri yang refrakter dan resisten terhadap terapi konvensional. Penggunaan RF memang kontroversi pada beberapa pasien dikarenakan adanya komplikasi neurologis akibat heat induce nerve damage. Sebagai alternative terapi digunakanlah pulsed radiofrekuensi. Pulsed radiofrekuensi (PRF) merupakan terapi dari jaringan saraf dengan kemungkinan neurodestructive yang kecil dan merupakan teknik alternatif untuk continue RF. Mekanisme kerja dari PRF saat ini sedang menjalani penelitian yang luas. Kebanyakan studi menunjukkan terjadi perubahan dalam transmisi sinaptik dan efek neuromodulator. Aplikasi radiofrekuensi di bidang neurologi cukup besar, efektifitas dari terapi PRF pada pasien dengan berbagai sindroma nyeri kronik telah banyak dilakukan studi retrospektif dan juga serial laporan kasus. Untuk menjelaskan mekanisme kerja dari radiofrekuensi dan menentukan true value nya pada manajemen nyeri penelitian-penelitian lebih lanjut masih sangat diperlukan.

\section{DAFTAR PUSTAKA}

1. Meliala, L, Pratiwi D . The Mechanism of Acute Pain; 2005.

2. Zhou, L. Principle of Pain Management. Elsevier; 2012. 44 (1): 783-801.

3. Manchikanti L. The role of radiofrequency in the management of complex regional pain syndrome. Curr Rev Pain; 2000. 4(6):437-444. Avalaible from: https://link.springer.com/article/10.1007/s11916-0000067-6

4. Lord SM, Bogduk N. Radiofrequency procedures in chronic pain. Best Pract Res Clin Anaesthesiol; 2002. 16: 597-617. DOI: 10.1053/bean.2002.0250

5. Kim JS, Nahm FS, Choi EJ, Lee PB, Lee GY. Pulsed radiofrequency lesioning of the axillary and suprascapular nerve in calcific tendinitis. The Korean Journal of Pain; 2012. 25(1):60-64. DOI: 10.3344/kjp. 2012.25.1.60.

6. Goldberg NS, Depuy DE 2001. Imaged guided radiofrequency part I. J vase interv 12. 1021-1032.

7. Hong K, Georgiades CS. Radiofrequency ablation mechanism of action and device. Thieme Medical Publisher. New York; 2011. pp 1-14.

8. William Rea, MRCP FRCA, Sandeep Kapur, FRCA FFPMRCA, Hirachand Mutagi, FRCA FFPMRCA. Radiofrequency therapies in chronic pain. Continuing Education in Anaesthesia Critical Care \& Pain; 2011. 11(2):35-38. DOI: 10.1093/bjaceaccp/mkq057

9. Callstrom MR, Charboneau JW, Goetz MP, Rubin J, Wong GY, Sloan JA, et al. Painful metastases involving bone: Feasibility of percutaneous CT- and US-guided radio-frequency ablation. Radiology; 2002. 224: 87-97. DOI: $10.1148 /$ radiol.2241011613

10. Van Zundert J, de Louw AJ, Joosten EA, Kessels AG, Honig W, Dederen PJ, et al. Pulsed and continuous radiofrequency current adjacent to the cervical dorsal root ganglion of the rat induces late cellular activity in the dorsal horn. Anesthesiology; 2005. 102:125-31. Avalaible

from: https://anesthesiology.pubs.asahq.org/article.aspx?articl eid=2025969 
11. Hata J, Karimi DP, DeSilva C, et al. Pulsed radiofrequency current in the treatment of Pain. Crit Rev Phys Rehabil Med; 2011. 23:213-40.

12. Higuchi Y, Nashold BS, Sluijter M, Cosman E, Pearlstein RD. Exposure of the dorsal root ganglion in rats to pulsed radiofrequency currents activates dorsal horn lamina I and II neurons. Neurosurgery; 2002. 50:850-856. DOI: 10.1097/00006123-20020400000030 .

13. Brace CL, Sampson LA, Hinshaw JL, Sandhu N, Lee FT. Radiofrequency ablation: Simultaneous application of multiple electrodes via switching creates larger, more confluent ablations than sequential application in a large animal model: "Sequential versus simultaneous RF ablation." Journal of Vascular And Interventional Radiology. JVIR; 2009. 20(1):118-124.

DOI: 10.1016/j.jvir.2008.09.021

14. Erdine S, Bilir A, Cosman ER, Cosman ER Jr. Ultrastructural changes in axons following exposure to pulsed radiofrequency fields. Pain Pract; 2009. 9(6):407-417. DOI: 10.1111/j.1533-2500.2009.00317.x

15. Tun K, Cemil B, Gurcay AG, Kaptanoglu E, Sargon MF, Tekdemir I, Comert A, Kanpolat Y. Ultrastructural evaluation of Pulsed Radiofrequency and Conventional Radiofrequency lesions in rat sciatic nerve. Surg Neurol; 2009. 72(5):496-500, discussion 501.

16. Van Kleef M, Spaans F. The effects of producing a radiofrequency lesion adjacent to the dorsal root ganglion in patients with thoracic segmental pain by radiofrequency percutaneous partial rhizotomy. Clin $\mathrm{J}$ Pain; 2002;11:325-332.

17. Koen Van Boxem, MD, PhD, FIPP, Nelleke de Meij, MSc, Alfons Kessels, MD, MSc, Maarten Van Kleef, MD, PhD, FIPP, Jan Van Zundert, MD, PhD, FIPP. Pulsed Radiofrequency for chronic intractable lumbosacral radicular pain: A six-month cohort study. Pain Medicine; 2015. 16(6):1155-1162. DOI: 10.1111/pme. 12670
18. Chua NH, Halim W, Beems T, Vissers KC. Pulsed radiofrequency treatment for trigeminal neuralgia. Anesth Pain Med; 2012. 1:257-261. DOI: 10.5812/aapm.3493

19. Van Kleef M, Liem L, Lousberg R, Barendse G, Kessels F, Sluijter M. Radiofrequency lesion adjacent to the dorsal root ganglion for cervicobrachial pain: A prospective double blind randomized study. J Neurosurg; 2006. 38.

20. Van Boxem K, Van Eerd M, Brinkhuizen T, Patijn J, Van Kleef M, Van Zundert. Radiofrequency and pulsed radiofrequency treatment of chronic pain syndromes. $\mathrm{J}$ Pain Practice; 2008. DOI: 10.1111/j.15332500.2008.00227.x

21. Erdine S, Ozyalcin NS, Cimen A, Celik M, Talu GK, Disci R. Comparison of pulsed radiofrequency with conventional radiofrequency in the treatment of idiopathic trigeminal neuralgia. Eur J Pain; 2007. 11:309-313. DOI: 10.1016/j.ejpain.2006.04.001

22. Manolitsis N, Elahi F. Pulsed radiofrequency for occipital neuralgia. Pain Physician; 2014. 17(6):E70917. Avalaible from: https://pubmed.ncbi.nlm.nih.gov/25415786/

23. Deniz Suleyman, Bakal Omer, Inangil Gokhan. Application of Radiofrequency in pain management; 2016. DOI: $10.5772 / 62859$

24. Amminof MJ. Occipital neuralgia in neurology and general medicine, 3 rd ed. Philadelphia. Churchill Livingstone; 2001.

25. Bradley et al. Complex regional pain syndrome type I : Reflex sympathetic dystrophy and type II : Causalgia in: John D Loeser ed., Bonica's Management of Pain Chapter 20 p388.

26. Akkoc Y, Uyar M, Oncu J, Ozcan Z, Durmaz B. Complex regional pain syndrome in a patient with spinal cord injury: Management with pulsed radiofrequency lumbar sympatholysis. Spinal Cord; 2008; 46:82-84. DOI: 10.1038/sj.sc.3102074 